Covered in: Web of Sciences (WOS); EBSCO; ERIH+; Google Scholar; Index Copernicus; Ideas RePeC; Econpapers; Socionet; CEEOL; Ulrich ProQuest; Cabell, Journalseek; Scipio; Philpapers; SHERPA/RoMEO repositories; KVK; WorldCat; CrossRef; CrossCheck

\section{A Parallel between the Art of Carving in Sculpture Masterpieces and the Carving Technique of Approaching Ski Turning}

\section{Camelia PLASTOI 1 , Ion POPESCU-BRĂDICENI², Adrian PICA ${ }^{3}$}

1 Assoc. prof. PhD., „Constantin Brâncuşı," University of Târgu-Jiu, Romania, cami plastoi@yahoo.com

$2 \mathrm{PhD}$ Lecturer, „Constantin Brâncuşi” University of Târgu-Jiu, Romania, gabrielapopescu51@yahoo.com

${ }^{3}$ Coach, School Sports Club, Petrosani, Romania, adipica@yahoo.com
Abstract: Constantin Brâncuşi brought the art of wood sculpting to its highest peaks. His technique is that of a master at work, turning wood into amazingly beautiful and yet modern shapes. His knowledge of the different textures of wood and its qualities enabled him to create organic sculptors that transcende modernity. His art combines the philosophy of life with that of the material. Brâncuşi provides fine arts with authenticity, force and sacredness. He searched and found the ideal shape, the psychedelic proportions and the Olympian equilibrium.

The shape of the carving whose, is and will remain a human ennoble art performance, building unmatched value and the final result. In skiing, the carving is a technique to cornering furthers what an ideal installments and perfect balance. With every movement outlines a special symbolic cornering, overtaken and its level of personalized training.

Keywords: grammar; skier gestures; achievement; hermeneutical interpretation; multidisciplinary approach.

How to cite: Plastoi, C., Popescu-Bradiceni, I., \& Pica, A. (2019). A Parallel between the Art of Carving in Sculpture Masterpieces and the Carving Technique of Approaching Ski Turning. Postmodern Openings, 10(3), 190-201. doi:10.18662/po/88 

A Parallel between the Art of Carving in Sculpture Masterpieces and the Carving ... Camelia PLASTOI, Ion POPESCU-BRĂDICENI, Adrian PICA

\section{Introduction}

In Oltenia, Gorj is the number one of the fourth largest and most important ethnographic areas, in which wood architecture and art are concerned. It has a long tradition of working with oak wood. Through Constantin Brâncuşi, the art of wood reaches its highest peaks on an international level. "The carvings of the front porch or tombs, those of the large wooden gates in Gorj, have unveiled over time the mastery in wood carving and shaping which Brâncuşi would gain in his unique way in his works, finishing it within the coordinates of an intensified modernism" and trans-modernism (Irimie \& Necula, 1983).

The master woodcarvers knew the properties of the different wood species and chose them according to their purpose and destination. They used common oak for building houses (due to its resistance to moisture and ants). They used beech tree (which cracks in a straight manner and bent on heat exposure) to make the roofing, the furniture and the household items for daily use. They used oak (essentially strong and very resistant) to build houses, fountains, sculpted gates and other objects with various patterns. They used acacia tree (resistant to moisture) to make barrels and fences and so on and so forth (Şerban \& Mischie, 2003).

Constantin Brâncuşi massively used oak wood in the creation of masterpieces: The small Frenchwoman-1914, Caryatid- 1915, The wasteful son1915, Chimera-1915, Adam and Eve -1916, Bench-1917, Gate-1917, Figure1917, Endless Column-1918, The Infinite Column-1920, The Infinite Column IV1920, The Infinite Column V-1920, The Infinite Column VI-1920. There are also Bench III-1920, The First step III-1920, Monument-1920, Guard Dog-1921, Medallion-1922, The King of Kings-1930, Wooden shape-1944, The portrait of lady Leone Ricon II-1914, 1919, The Screw-1930, Corner chair II (Mocioi, 2003).

He worked other types of wood with the same results: maple: Torso of a boy-1917, The shop gate-1923. Walnut: Torso of a boy II-1923, The rooster-1924, Cassette-1898. Cork wood: Spoon-1922. Linden: Small chair V-1928, Frame I1898, Frame II, 1897-1898, Frame III, 1897-1898. Sycamore maple: Loom1896. Pear tree: The crawling tortoise-1943. Cherry tree: Lotto-1896 (Brezianu, 1976).

From Bavarian old oak the great sculptor, born in Hobița and schooled in Brădiceni, Gorj, created other masterpieces of archetypal meaning. The First cry-1912, Caryatid II a -1914, The Portrait of lady Léone Ricon (I), 1914; The First step II-1914; A Study for the portrait of misses Meyer (I), (1916); Eve-1916, A cup (I), 1917; A cup (II a)-1917; Adam -1917, Architectural 
project I- 1918. The Endless Column (I)-1918; The Small Frenchwoman (II)-1919; The study of a bird-1919, Plato (I a)-1920; Plato (I b)- 1920; The head-1920; Small chair I-1920, Small chair II, III and IV-1920, Socrates (II)-1923; The Rooster (I a)1923, The Boss (I) and (II)-1924; The Fish II-1924; A Cup IV-1925; The Portrait of Nancy Cunard/A Young sophisticated girl (I)- 1925; A Study for the king of kings/Buddha's spirit-1930, Nocturnal Animal-1930, A V ase -1935, Figure-1944, Portrait-1915, Caryatid cat - 1916-1923; Element of the endless column -1937; The Head of the first step (I), 1913-1915; Crocodile- 1925; Portrait -1930; Ark-1920; Distaff-1922.

In Romania, there was a mass phenomenon of practicing woodcarvings as a tradition and a legacy of our civilization. Saying about this phenomenon, in 1983, Irimie \& Necula mentioned in their book that, excelling in both monumental structures and household items linked to practicing some traditional occupations, one highlights first of all Maramureş and Gorj, whose civilizations and wood art are inscribed as a contribution of great cultural patrimony value to Europe alongside similar works by Scandinavian or Austrian Tyrol or in Germanic Bavaria. (Irimie \& Necula, 1983).

The southern Carpathians Gorj has fir and pine forests and oak ones on the rolling hills. Oak is a dense fiber wood, good for massive structures and easy to sculpt and carve. Among the powerful wood carvers centers there are those from Novaci, Peştişani, Tismana, Arcani, Runcu, Dobriţa, Polovragi, Baia de Fier, Hobiţa and Brădiceni. At Brădiceni, Câmpofeni and Pocruia, one can still see dysfunctional watermills, which are in ruins and almost destroyed by time. Some moved to the open air Museum at Curtişoara, where, still, the conservation process less desired because of the lack of funding.

\section{Developing the idea}

The resemblance between the values left in the history by art of applying carving in specific forms and in different ways, converge toward mastery and excellence regardless of the generations they have created.

The experience gained in the educational/research activities and the training of the athletes for the acquisition of their motor skills enabled us to argue the major link to the notion of cutting, expressed in art and the form to manifestation of a ski technique, specific to the alpine skiing. The mastery of sculpting by cutting, becoming art under the impact of expression through the artist's quality and ingenuity, as well as the depth of storage of motor information by athletes exteriorized through the shapes, moments 
and movements performed with the whole body segments so that, the carving method of skiing shows sport performance, generates the emphasis on complexity and similarity between contoured shapes cuts in art and sports.

The philosophical-didactic-sporting collaboration created a major interdisciplinary approach to the artistic forms of cutting from simple executions and finalizing by generating elevated, perceptible but at the same time perfect reaching the ideal in performance and art, the symbolic interpretation being highlighted in the present material by reconfiguration and argumentation of the high performance of the cutting phenomenon through the theoretical and practical experiences of the authors. The dedication, in equally measure of authors at elaboration to work, resolved and redesigned the aspect by which the results generated from the hard work are integral part of the performances obtain, the excellence in execution, both in art and sport, being perceived and assimilated without linguistic boundaries, but conditional success and generating immortality in edification.

This material expresses a parallel between the art of carving in sculpture masterpieces and the carving technique of approaching ski turning, mentioning with infinite respect and total admiration the creations values and the endless potential of the human being.

Constantin Brâncuşi is the heir of a whole series of craftsmen of Gorj tradition: carpenter, joiners, roof makers, coopers, spoon makers, carvers in soft wood essences, craftsmen of musical instruments which conditioned their products according to the specificity of the wooden essences and the qualities of the harnessed wood: hardness, resistance, elasticity, fiber structure and color.

Like the ones above, the author of the three monuments at Târgu-Jiu saw the new relationship between substance and essence. I quote one must feed on the essence of art in order to understand its value, given to it by the process of trans-substantiation (Popescu-Brădiceni, 2009a), where he used the soft essences (corkwood, linden, cherry wood, and pine) as well as the harder ones: oak, maple pear wood. Oak was his main raw material. This is also because in Gorj this type of wood the artisans used in architecture. Constantin Brâncuşi was a sculptor with architectural obsessions like the Temple of Indore and The Sculptural works at Târgu-Jiu. Like Buliga says the first was to represent a temple of the liberation of the soul from the body, that of contemplation and meditation with the shape of an egg (Buliga, 2009) and Muntenuş (2008), the same, the sculptural ensemble was destined and conceived as a funerary temple, a temple for the cult of the ancestors, a 
temple of the historic and mythical/symbolic time, as a temple of tradition (Muntenuş, 2008).

Oak was synonymous in Greek-Roman culture with strength and power and in Japanese culture with luck and the protective forces. "Although Jews associated oak with paganism, they also kept the tradition of its link to the supernatural (Shepard \& Shepard, 1998).

In Romania, oak is one of the most important sacred trees (Evseev, 2007). By its shadow in a grove from a primer in ever wider circles, unraveling towards the shores of a see crossed by Achaeans (PopescuBradiceni, 2009b), let us not forget that the name "grove" (dumbravă) derives from an Indo-European word which means "oak". The oak is a mythical tree, a totemic tree, because in the order of the important vegetal essences from a magical point of view, the oak is next after the pine tree.

Amongst all the forms of veneration of which it belongs in Romanian traditional culture, it integrates in the area of the spirituality of the Indo-European peoples, spread over a vast territory from the river Indus to the Ganges and the Atlantic coast (Popescu-Brădiceni, 2009a).

As Constantin Brâncuşi was a worldwide figure, a paradigm of the semiotics and symbolism of the oak would not be superficial at all:

- Ancient Greeks thought the oak tree to be consecrated to Zeus (see Zeus's oak from Dodona);

- In Rome the oak tree was dedicated to Jupiter;

- the old Slavs thought that Perun had this tree as an attribute;

- The Celtic and Germanic tradition assimilated it with the gods of thunder: Donar, Tanaris and Thor;

- in the crown of the oak there grew the mistletoe and in its presence, there were the Druids priests.

- Oak is of tough essence; the tree impresses through its huge, fabulous size, through its longevity, through its power to withstand to all the hardships that time throws at it;

- there is a long cultural tradition that has made these great trees the symbol of physical and psychological strength; of durability and majesties;

- the oak is an axial tree, which assures the link between the three worlds: underground, terrestrial and celestial;

- the oak is a metaphor of man who does not let himself brought down by faith; it is an allegory of his moral verticality; it is also a symbol of the behavior of Romanian sportsmen, of champions; in ancient times they received a wreath made from oak lives, as a sign of great respect and recognition of their value; 
- in Latin, the oak and the force share the same name "robur" which symbolizes - as I have mentioned before - both the physical and mental strength; it has the value of a temple; the human body, if that of a champion, is celebrated as a temple (Chevalier \& Gheerbrant, 1995).

In Brâncuşi aphorisms, the sculptor himself, born in Gorj, Hobița refers to wood, Zărnescu (1994) says, the wood, for example, is in itself, under all aspects, sculptural by nature. One must not destroy it and give it an objective resemblance to something that nature constructed from another material. Wood has its own shapes, its individual character and natural expression; the desire to morph its qualities is equal to destroying and making it sterile. Wood as other materials must continue its existence and suggest the subject and shape which are to come together from within matter itself and are not imposed from the outside (Zărnescu, 1994). And in the same way in the artists opinion sculpture remains an expression of the action of nature. The artist must know how to make the being inside matter emerges and to also be a tool which brings forth the very cosmic essence of it in a truly visible existence; to place one's spirit in harmony with the spirit of the material world (Zărnescu, 1994).

"Therefore one cannot turn marble into the kind of material that wood is, nor can one use wood as if it were of stony essence" (Zărnescu, 1994). Consequently, you would combine all shapes in a perfect unity and give them life. Then you would only talk about that sculpture which is alive and not about any other that would imitate life. "If art must join with nature to express its principles, it must follow the example of action. Matter must continue its life even after the sculptor's hand would have intervened" (Zărnescu, 1994).

Action arises from the dynamic qualities of terrestrial forms and shapes. Brâncuşi' interior memory was powerfully sensitive to the grandeur of cosmic and earthly events. One "struggled to imaginary resurrect the testimony of the passing time and pulse in present things" (Ailincăi, 2000). It became aware that one must return to the beginning of things and to retrieve what was lost; everything, every being or non-being has a spirit; the spirit would always be alive (Zărnescu, 1994).

In this manner, Brâncuşi suggested what he wanted to represent; he used bronze, wood and marble to bring out that hidden diamond which is "the existence". Every man has a diamond. The artist would work this diamond and force it to be cut in s dozen facets following the shape he saw in his heart and from his interior dream (Zărnescu, 1994). The shape would reveal itself to the interior meditation and originally motivated by a very profound feeling and by the ambition to find the existential truth. This truth 
is reality. "That which is real is nothing but essence. Should one reach the real essence of things, one would find it is true simplicity" (Zărnescu, 1994). It could also be "the golden fraction", the "interior proportion". Yet, simplicity is not a purpose in art; one reaches simplicity without one's desire, getting ever closer to the real meaning of things. Simplicity is but complexity in itself; "one must feed of the essence to understand its value". The shape of the artistic object represents the "the shape of the idea itself and would be the measure of its own being". While "there is a purpose in all things", "the accident can be turned into a universal law" (Zărnescu, 1994).

Just as in a sport by approaching pluri- and inter-disciplinary body modelling, it enables starting from simple executions to reach the accumulation of theoretical and practical knowledge meant to generate elevated gesture interpretations. The elevated gestures perception and at the same time perfection reach the ideal in interpretation and symbolistic emphasized (Chera-Ferrario, Popescu-Bradiceni, \& Pica, 2019).

The pleasure to carve from Brancusi and desire of the skier to apply the carve technique can be found in "the manifestation of the desire of the adult age to acquire new skills that involve learning the alpine ski and practicing it as a free time activity would allow to overcome some barriers, to find motivation and determination to make a physical and mental effort to assimilate new theoretical information with practical applicability". (Plastoi, 2017)

A fundamental aspect becomes obvious: Constantin Brâncuşi was a philosopher of art for as long as he lived and worked. Upon returning to wood as a material, oak in particular, Brâncuşi reserved wood the uneven shapes and wrinkled surfaces, the complex shapes and rough finish. Very few of the wooden things he made he actually sanded and those finished he made of bronze. Among almost a dozen works just a few were transposed from wood to bronze: The first cry-1911, A young man's torso-1916, The rooster1924, The portrait of Nancy Cunard -1928.

In order to form an opinion on the semiotics and symbolism of cellulose from several species of wood (fir tree, spruce, pine tree, birch, beech, poplar, oak), we browsed through an old organic chemistry textbook speaking about the significance of the $\mathrm{D}$ and $\mathrm{L}$ symbols and the methods by which these symbols were attributed to every substance in this class. The colloid character of the solutions of this substance is a sign that oak cellulose has a macromolecular structure. The compounds embedding such a structure would char if heated above $300^{\circ} \mathrm{C}$. "The X-ray spectrum was of tremendous of help in establishing the structure of cellulose. In spite of its amorphous spectrum, cellulose behaves like a crystalline substance when 
exposed to x-rays. The crystalline network's elementary cell is crossed by five macromolecules" (Nemțescu, 2003), but Brâncuşi used wood to create, in many ways, fantastic shapes, which are either grotesque or they are full of spirit -The caryatids (Spear, 1976).

The spatial representation of the elementary cell resembles that of a cube. The fibrillose structure of cellulose has crystalline regions, which feature a parallel orientation of macromolecules and amorphous areas. Constantin Brâncuşi took these molecular characteristics and the polymerization grades of the different types of trees into account when he used them to sculpt objects of art. The mechanical solidity of the wood itself and its mechanical resistance at break were very important; also there was the water insolubility (determined by the large number of hydrogen links between macromolecules), or the hygroscopic feature. The x-ray spectrum of water saturated cellulose is identical to that of dry cellulose; "water attaches only to the outer most parts of the crystallites, reaching just as far as the amorphous, less compact fiber regions" (Nemțescu, 2003).

Wood is a compact aggregate of cells and channels/veins through which the plant's sap circulates. In a dry state, wood contains cellulose, lignin, herm-cellulose and ash (the inlay is insignificant and taken into account when establishing the composition of the wood species). Lignin plays a role similar to that of concrete whilst cellulose to that of iron in reinforced concrete. These should be enough reasons to understand Constantin Brâncuşi choice to use wood with the same unshaken trust with which he would have used marble, stone and metal (ferrous and nonferrous).

The problem that arises why are all wood sculptures made almost entirely of oak (Bavaria Romanian oak or saved from the Paris demolitions). Hardwoods' lignin contains 21-22\% metoxil groups. Hardwood lignin used to obtain vanillin and Aldehyde but also Gallic acid trimethyl ether. One can only deduce that hardwood lignin contains, besides the ring of guajacol a ring of ether 1.3-diethyl pirogalol. Any lignin formed de facto through dehydrogenated copolymerization of alcohol p-Hydroxycinnamic with pine alcohol and sinapic alcohol. In beech lignin, the three alcohols probably appear in proportion 4:49:46 (Nemțescu, 2003).

The complicated structures of lignin amaze us through their rhomboidal shapes similar to those of the Endless Column or from the many supports of Brâncuşi' sculpture, sculpted in a spiral (like Miss Pogany from 1933) in order to better accompany the movement of sculpture made from "arches, curves and pearly bindings; and pure shells" (Jean Arp) (Tabart, 1995). 
In fact, the tree as a double vegetal essence of man has maintained its millennia significance in almost all spiritual-cultural models of this old region of Gorj. The sculptor believed that the ego must reenter the collectivity anonymously. That is why he eliminated the religious and created in beauty, force and vitality, in euphoria and optimism (dosed with the melancholic meditation), even if Pandrea say that, Constantin Brâncuşi studied and admired the veins and delicacy of oak wood and walnut wood and the finesse of poplars from the simple reason that "wood is a friendly material (Pandrea, 2009), almost human.

\section{Discussions}

By sculpting wood, the artist from Hobița has rediscovered the volume, the shapes, the substance, symmetry and the regularities of beauty and of nature. He searched and found the ideal shape, the psychedelic proportions and the Olympian equilibrium. More often than not, the shape is that of a fountain (Narcissus Fountain), a Drowsy Muse, The Earth's Chastity, but also The Majestic, the 1912 Pedestal of the Majestic; they are all geometric art with reliefs imitating tree bark from forests. Petre Pandrea (2009) notices that by closely analyzing the relief one can "distinguish sketches of legendary, human figures from the beginning of the world maybe human-like or degenerate monsters from the end of the world".

The geometric principle is similar to that of poetry in Brâncuşi's case and strictly applied to both wood and bronze. Therefore, the Rooster reaches for the sky, dry and mathematical, but with an ancestral vibe like James Joyce from Finnegan's Wake.

Brâncuşi's art has exemplary combined the philosophy of the body with the philosophy of the material. Its head is sturdy, releasing inexhaustible energies. "Dedication in equal extent in framing the article resynthesized and designed the aspect through which the totality of our gestures are part of obtaining the performance, the body language being perceived and assimilated without linguistic boundaries, yet being a condition of the success" (Chera-Ferrario et al., 2019).

Anchored in a philosophy of life (lebensphilosophie) that is to say an organic, vital and naturalistic one, the sculptor believed, like Joyce and Mircea Eliade in the "eternal comeback" that he imagined in the form of a spiral. For him, "nature is materialized in laws, humans and the society develop in regularities in the vital fluid which is to be deciphered and put into formulas. 
The formula of cellulose and lignin is beneficial in this study. One can see in the first part of our research their important role for a hermeneutist and semiotics scholar. There is a Carpathian-European influence in the philosophy of Constantin Brâncuşi. This influence joins the oriental one. The shining stylistic and its theoretical complexity borrow from Vico and Nietzsche the materialistic part from Romanian Vasile Conta. In essence, life as an expression of the troubling destiny leads to serenity, to euphoria and to self-detachment. From this telluric and self-defense position there derives the vitality and geometric Brâncuşian abstractionism. These are not in contradiction. There are two facts. Destiny has rules that materialized in the rules that move stars, in fixed seasons, in the relatively static nature of ages and of biological human existence, in the regularity of the growth of Carpathian forests and plants. These static things are abstractions dictated by mathematics. Besides the movement of constellations, we have the movement of man through history (Pandrea, 2009).

\section{Conclusions}

Brâncuşi brought back the vitality, the sacred arch, the force, the energetic personality, beauty and authenticity to fine arts, thus turning art into an ever more powerful and major entity, an expression of the critical balance between abstraction and representation. He used wood to carve uneven surfaces, complex or perforated shapes and the minimalistic finishing touch (Spear, 1976). However, he used marble because of the reason that 'wood has far too big a grainy texture and it is too uncertain to allow the development of a shape so subtle and precise like The Bird.

Moreover, it does not have the noblesse and transparence of marble; its total opacity and concreteness does not coincide with the expression of immateriality or preciousness, which also happened to be amongst Brâncuşi' highest goals. He used wood for fantastic, grotesque, full of spirit shapes in the form of pedestals (The Caryatids) or pieces of furniture (Spear, 1976).

An important role in these assimilations was also the personal determination the individual had in shaping new skills in different fields like sports man and like an artist yet, this observed in time, they dissolved their material body, changing into sources of light. By wearing their sacred aura, they will have enjoyed the trans-modern and trans-temporal solar or earthly gods (s.n.).

The Endless Column was forged to be a god that "would perpetually reach for the sky through (and like) real trees (Spear, 1976) to create an organic rising movement. 
In other words, Brâncuşi projected himself within the object so that the object would speak on behalf of the artist. Consequently, his woodwork is as much Western as it is Oriental (see the influences from Milarepa, Zen Buddhism and Romanian archaic.

Marielle Tabart ads three more points to the already existing ones: the humor and taste for bindings and crossovers; the integration of the spirit that crosses nature in the spirit that breathes (Tabart, 1995).

\section{References}

Ailincăi, C. (2000). Gramatica formelor vizuale [The grammar of visual shapes]. Pitești, Romania: Paralela 45.

Brezianu, B. (1976). Brâncuşi in Romania. Bucharest, Romania: Editura Academiei.

Buliga, S. (2009). Simbolositică sacra in opera lui Constantin Brîncuşi [The Sacred symbolism in Constantin Brâncuşi' works]. Craiova, Romania: Scrisul Românesc.

Chera-Ferrario, B., Popescu-Bradiceni, I., \& Pica, A. (2019). The vision of hermeneutic interpretation upon the skiers' gestures. Postmodern Openings, 10(2), 114-124. doi:10.18662/po/74

Chevalier, J., \& Gheerbrant, A. (1995). Diçtionar de simboluri [A dictionary of symbols] ( $3^{\text {rd }}$ vol.). Bucharest, Romania: Artemis.

Evseev, I. (2007). Diçtionar de simboluri [A dictionary of symbols]. Bucharest, Romania: Vox.

Irimie, C., \& Necula, M. (1983). Arta țărănească a lemnului [The traditional wood art]. Bucharest, Romania: Meridiane.

Mocioi, I. (2003). Brâncuşi. Opera [Brâncuşi. His works]. Târgu-Jiu, Romania: Spicon \& Drim Edit.

Muntenuş, H. (2008). Dincolo de Brâncuşi [Beyond Brâncuşi]. Cluj-Napoca, Romania: Geodo.

Nemțescu, C. D. (2003). Chimie organică [Organic chemistry] (2nd \& $7^{\text {th }}$ vol.). Bucharest, Romania: Didactică și Pedagogică.

Pandrea, P. (2009). Brâncuşi, amintiri și exegeze [Brâncuși, memories and exegetics]. Bucharest, Romania: Vremea.

Plastoi, C. (2017). Positive effects on the adult human body of alpine skiing practiced as a freetime activity. Scientific Report Physical Education and Sport, 21(1).

Popescu-Brădiceni, I. (2009a). Arca Metanoia - Traiada tipologică de la Târgu-Jiu:

Tăcerea, Sărutul, Infinitul [Metanoia Ark. Typological triad at Târgu-Jiu: The Silence, The Kiss, The Infinite]. Târgu-Jiu, Romania: Măiastra. 
A Parallel between the Art of Carving in Sculpture Masterpieces and the Carving ... Camelia PLASTOI, Ion POPESCU-BRĂDICENI, Adrian PICA

Popescu-Brădiceni, I., (2009b). Arca metanoia. Majordomul palatului [Metanoia ark. The Byzantium chronicler]. Târgu-Jiu, Romania: Măiastra.

Shepard, R., \& Shepard, R. (1998). 1000 de simboluri. Semnificația formelor în artă şi mitologie [1000 symbols. The significance of the shapes in art and mythology]. Oradea, Romania: Aquila.

Spear, A. (1976). Păsările lui Brâncuşi [Brâncuşi’ birds]. Bucharest, Romania: Meridiane.

Şerban, D. A., \& Mischie, N. (2003). Woodworks. Wood craftsmen. In Traditional craftsmanship and Gorj craftsmen (pp. 29-30). Phabon .

Tabart, A. M. (1995). Brâncuşi - Inventatorul sculpturii modern [Brâncuşi- The inventor of modern sculpture]. Bucharest, Romania: Univers.

Zărnescu, C. (1994). Aforismele lui Brâncuşi [Brâncuşi aphorisms]. Cluj-Napoca, Romania: Fapta Transilvăneană \& Zalmoxis. 